Preprint, for presentation at the 213th ACS National Meeting to be held in San Francisco, CA on April 13-17, 1997.

\author{
RFCFIVED \\ APR 141997 \\ USTI
}

LINKAGES BETWEEN AROMATIC STRUCTURES IN THE

ARGONNE PREMIUM COAL SAMPLES*

\author{
Randall E. Winans and Nancy A. Tomczyk \\ Chemistry Division \\ Argonne National Laboratory \\ Argonne, IL 60439
}
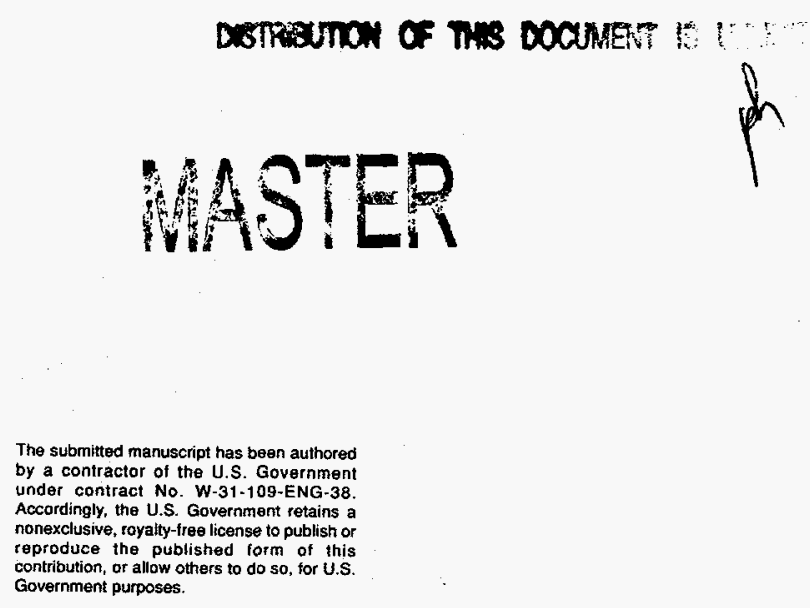

*This work was performed under the auspices of the Office of Basic Energy Sciences, Division of Chemical Sciences, U.S. Department of Energy, under contract number W-31-109-ENG-38. 


\section{DISCLAMMER}

Portions of this document may be illegible in electronic image products. Images are produced from the best available original docoment. 


\section{DISCLAIMER}

This report was prepared as an account of work sponsored by an agency of the United States Government. Neither the United States Government nor any agency thereof, nor any of their employees, make any warranty, express or implied, or assumes any legal liability or responsibility for the accuracy, completeness, or usefulness of any information, apparatus, product, or process disclosed, or represents that its use would not infringe privately owned rights. Reference herein to any specific commercial product, process, or service by trade name, trademark, manufacturer, or otherwise does not necessarily constitute or imply its endorsement, recommendation, or favoring by the United States Government or any agency thereof. The views and opinions of authors expressed herein do not necessarily state or reflect those of the United States Government or any agency thereof. 


\title{
LINKAGES BETWEEN AROMATIC STRUCTURES IN THE ARGONNE PREMIUM COAL SAMPLES
}

\author{
Randall E. Winans and Nancy A. Tomczyk \\ Chemistry Division \\ Argonne National Laboratory \\ Argonne, IL 60439
}

Keywords: Argonne coals, structure lengths, mass spectrometry

\begin{abstract}
The objective of this study is to elucidate the nature of the important linkages between aromatic clusters and variations of these links with coal rank. From studies using methods such as NMR and mass spectrometry, we have considerable information on the size and types of aromatic clusters in the Argonne coals. In this study, extracts, model polymers, extracted coals, and modified coals are examined by temperature resolved high resolution mass spectrometry. There is evidence that strong bond cleavage may be very important for volatile release in pyrolysis of higher rank coals.
\end{abstract}

\section{INTRODUCTION}

There is significant general information on the size and nature of the aromatic structures in coals, especially the Argonne Premium Coal Samples. A battery of methods have been used yielding global information by NMR, ${ }^{\prime}$ XANES, ${ }^{2,3,4}$ XPS, ${ }^{5}$ and TGFTIR, ${ }^{6,7}$ and more specific class and size distribution by FIMS, ${ }^{8}$ HRMS,${ }^{9,10}$ and LDMS. ${ }^{11}$ The nature and distribution of the linkages between these clusters is less well defined but are obviously important in any thermal process. A large number of studies have been done on the pyrolysis of the Argonne coals, for example: modified Rock-Eval pyrolysis, ${ }^{12}$ pyrolysis MS, ${ }^{8,12}$ and TGFTRR ${ }^{6,7}$ It has been assumed that ethylene linkages are important in coals and that they are reactive. However, there is no direct evidence that this is the case.

\section{EXPERIMENTAL}

A complete description of the Argonne Premium Coal Samples is available via internet at: http://www.anl.gov/PCS/pcshome.html and has been published..$^{13}$ Important analytical data on the coals and pyridine extracts ${ }^{11}$ are shown in Table 1 . Nitrogen values are fairly constant between 1.3$1.7 \mathrm{~N} / 100$ carbons.

Desorption high resolution mass spectra are taken on a 3-sector MS-50 either in electron impact or chemical ionization mode. Samples are heated from 200 to $700^{\circ} \mathrm{C}$ at $200^{\circ} \mathrm{C} / \mathrm{min}$ on a probe directly in the source. The chemical ionization gas used was iso-butane. A Diels-Alder adduct of maleic anhydride and perdeuteroanthracene is used as an internal standard. Precise mass measurements are averaged from scans over the entire temperature range. Formulae are assigned and the data sorted via a procedure developed in this program. Only formulae that fit within \pm 3.5 millimass units are considered.

Table A- 1. Selected Analysis and Yields for the Argonne Premium Coal Samples.

\begin{tabular}{|c|c|c|c|c|c|c|c|c|}
\hline \multirow{3}{*}{$\begin{array}{c}\text { Sample } \\
\#\end{array}$} & \multirow[b]{3}{*}{ Name } & \multirow[b]{3}{*}{$\% \mathrm{C}$} & \multicolumn{5}{|c|}{ Per 100 Carbons } & \multirow{3}{*}{$\begin{array}{l}\text { Pyridine } \\
\text { Solubles } \\
\text { Yield (w\%) }\end{array}$} \\
\hline & & & \multirow[b]{2}{*}{$\mathbf{H}$} & \multirow[b]{2}{*}{$\mathrm{S}$} & \multicolumn{3}{|c|}{0} & \\
\hline & & & & & $a$ & $\boldsymbol{b}$ & $c$ & \\
\hline 8 & Beulah-Zap & 74.1 & 80 & 0.4 & 21 & 31 & 7.7 & 18 \\
\hline 2 & Wyodak-Anderson & 76.0 & 86 & 0.2 & 18 & 22 & 7.3 & 29 \\
\hline 3 & Illinois \#6 & 80.7 & 77 & 1.2 & 13 & 10 & 5.0 & 29 \\
\hline 6 & Blind Canyon & 81.3 & 86 & 0.2 & 11 & 12 & 7.4 & 25 \\
\hline 4 & Pittsburgh & 85.0 & 77 & 0.4 & 8 & 9 & 6.0 & 24 \\
\hline 7 & Lewiston-Stockton & 85.5 & 76 & 0.3 & 9 & 10 & 6.7 & 17 \\
\hline 1 & Upper Freeport & 88.1 & 66 & 0.3 & 7 & 8 & 6.4 & 28 \\
\hline 5 & Pocahontas \#3 & 91.8 & 59 & 0.2 & 2 & 4 & 3.7 & 3 \\
\hline
\end{tabular}

$a-$ Coal

$b$ - Extract

$c$ - Furans and Ethers 
High resolution mass spectrometry data can be sorted by both heteroatom content and by hydrogen deficiency which is also termed double bond equivalents and is related to z-number. From hydrogen deficiency, the size of aromatic clusters can be estimated.

\section{RESULTS AND DISCUSSION}

In absolute numbers of oxygens per 100 carbon atoms determined by HRMS, the furans plus ethers are relatively constant compared to the total oxygen in the extracts as is shown in Table 1. This would suggest that the influence of these types of structures are relatively important and constant across all ranks for vitrinite rich coals.

Because of these results, we decided to reinvestigate the reactivity of a model polymer with ether links. DCIMS results were examined since ions observed are the result of thermal fragmentation and not fragmentation in the source of the spectrometer. From the mass spectra recorded as a function of temperature a series of products were observed and are shown in Scheme 1 along with the polymer (I). ${ }^{14}$<smiles>[X]CCOc1ccc(OCc2ccc(CC)c3ccccc23)cc1</smiles>

1<smiles>Cc1ccc(C)c2ccccc12</smiles>

II<smiles>Cc1cccc2ccccc12</smiles>

VI<smiles>Oc1ccc(O)cc1</smiles>

III

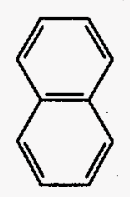

IV

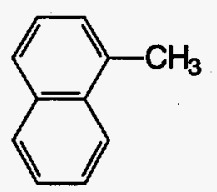

V<smiles>Cc1ccc(O)cc1</smiles>

Scheme 1

Strong bond cleavages occur at higher temperatures which would yield naphthalene (IV) and methyl naphthalene, and especially with the rearranged polymer resulting in VI and VII. For example, the naphthalene yield, which only can be formed from cleavage of strong bonds, is maximum at $500^{\circ} \mathrm{C}$. In contrast, dihydroxybenzene $(\mathrm{m} / \mathrm{z}=110)$ and dimethylnaphthalene peak at $300^{\circ} \mathrm{C}$. In Figure $1 \mathrm{a}$, the temperature profile for dihydroxybenzene is compared between the polymer and the Illinois coal (APCS 3) extract. The coal yields below $400^{\circ} \mathrm{C}$ are very small and maximize between $400-500^{\circ} \mathrm{C}$ which would suggest that the bonding is not via oxygen-methylene linkages as is the case for the polymer. Ring methylated dihydrobenzene (VII) results from rearrangement of the polymer followed by cleavage. It is probably represented in the second peak for $\mathrm{m} / \mathrm{z}=124$ at $\sim 475^{\circ} \mathrm{C}$ (see Figure $1 \mathrm{~b}$ ). The Illinois bituminous coal has a maximum at this temperature and several at even higher temperatures. While the low rank subbituminous coal is very broad and has a maximum at even a higher temperature; this broad type of distribution was also observed for phenol in lignite pyrolysis. ${ }^{12}$ The oxygen functionality is likely to be undergoing some secondary reactions prior to release from the macromolecular matrix.

Burnham, et al. ${ }^{12}$ using PyMS noticed greater high temperature tails for small unsubstituted aromatics compared to corresponding methyl derivatives for the higher rank coals. They suggested that this may be due to increased breaking of Ar-Ar bonds. We observed in the high rank coals that 
larger aromatics are released in greater quantities at high temperature compared to lower temperature while substituted aromatics tend to be more abundant at lower temperature. In Figure 1c, we observed this effect for pyrene/fluoranthene $(\mathrm{m} / \mathrm{z}=202)$ compared to $C_{2}$-pyrene $(\mathrm{m} / \mathrm{z}=230)$ for the Pocahontas extract. In the lower rank Pittsburgh seam coal (Figure 1d), the unsubstituted pyrene which can only be released by strong bond breaking, is still more abundant at high temperatures, but in addition, the alkylated aromatic is also released at higher temperatures.

\section{CONCLUSIONS}

The evidence suggests the strong bond breaking in pyrolysis is significant in higher rank coals and could play a role in the lower rank coal pyrolysis. We are examining methods to better quantitate the extent of these types of cleavages in coal pyrolysis.

\section{ACKNOWLEDGMENTS}

This work was performed under the auspices of the Office of Basic Energy Sciences, Division of Chemical Sciences, U.S. Department of Energy, under contract number W-31-109-ENG-38.

\section{REFERENCES}

1. T. H. Fletcher, S. Bai, R. J. Pugmire, M. S. Solum, S. Wood, and D. M. Grant, Energy Fuels 7. 734 (1993).

2. G. N. George, M. L. Gorbaty, S. R. Kelemen, and M. Sansone, Energy Fuels 5, 93 (1991).

3. G. P. Huffman, S. Mitra, F. E. Huggins, N. Shah, S. Vaidya, and F. Lu, Energy Fuels 5 , 574 (1991).

4. S. Mitra-Kirtley, O. C. Mullins, J. Branthaver, J. Van Elp, and S. P. Cramer, Prepr., Div. Fuel Chem., $A C S \underline{\text { 38, }} 756$ (1993).

5. S. R. Kelemen, M. L. Gorbaty, and P. J. Kwiatek, Energy Fuels $\underline{8}, 896$ (1994).

6. R. Bassilakis, Y. Zhao, P. R. Solomon, and M. A. Serio, Energy Fuels 1, 710 (1993).

7. P. R. Solomon, M. A. Serio, R. M. Carangelo, and R. Bassilakis, Energy Fuels 4, 319 (1990).

8. N. Simmleit, H.-R. Schulten, Y. Yan, and H. L. C. Meuzelaar, "Thermochemical Analysis of U.S. Argonne Premium Coal Samples by Time-Resolved Pyrolysis FIMS," in Advances in Coal Spectroscopy, H. L. C. Meuzelaar (ed.), Plenum Press, New York, 1992, 295.

9. R. E. Winans, Y. Kim, J. E. Hunt, and R. L. McBeth, Proceedings, 1995 International Conference on Coal Science, Oviedo, Spain (1995), 87.

10. R. E. Winans, "Mass Spectrometric Studies of Coals and Coal Macerals," in Advances in Coal Spectroscopy, H. L. C. Meuzelaar (ed.), Plenum Press, New York, 1992, 255.

11. J. E. Hunt and R. E. Winans, Proceedings, 1995 International Conference on Coal Science, Oviedo, Spain (1995), 319.

12. A. K. Burnham, M. S. Oh, and R. W. Crawford, Energy Fuels 3, 42 (1989).

13. K. S. Vorres, Energy Fuels 4, 420 (1990).

14. T. G. Squires, B. F. Smith, R. E. Winans, R. G. Scott, and R. Hayatsu, Proceedings, 1983 International Conference on Coal Science, Pittsburgh, PA (1983), 292. 

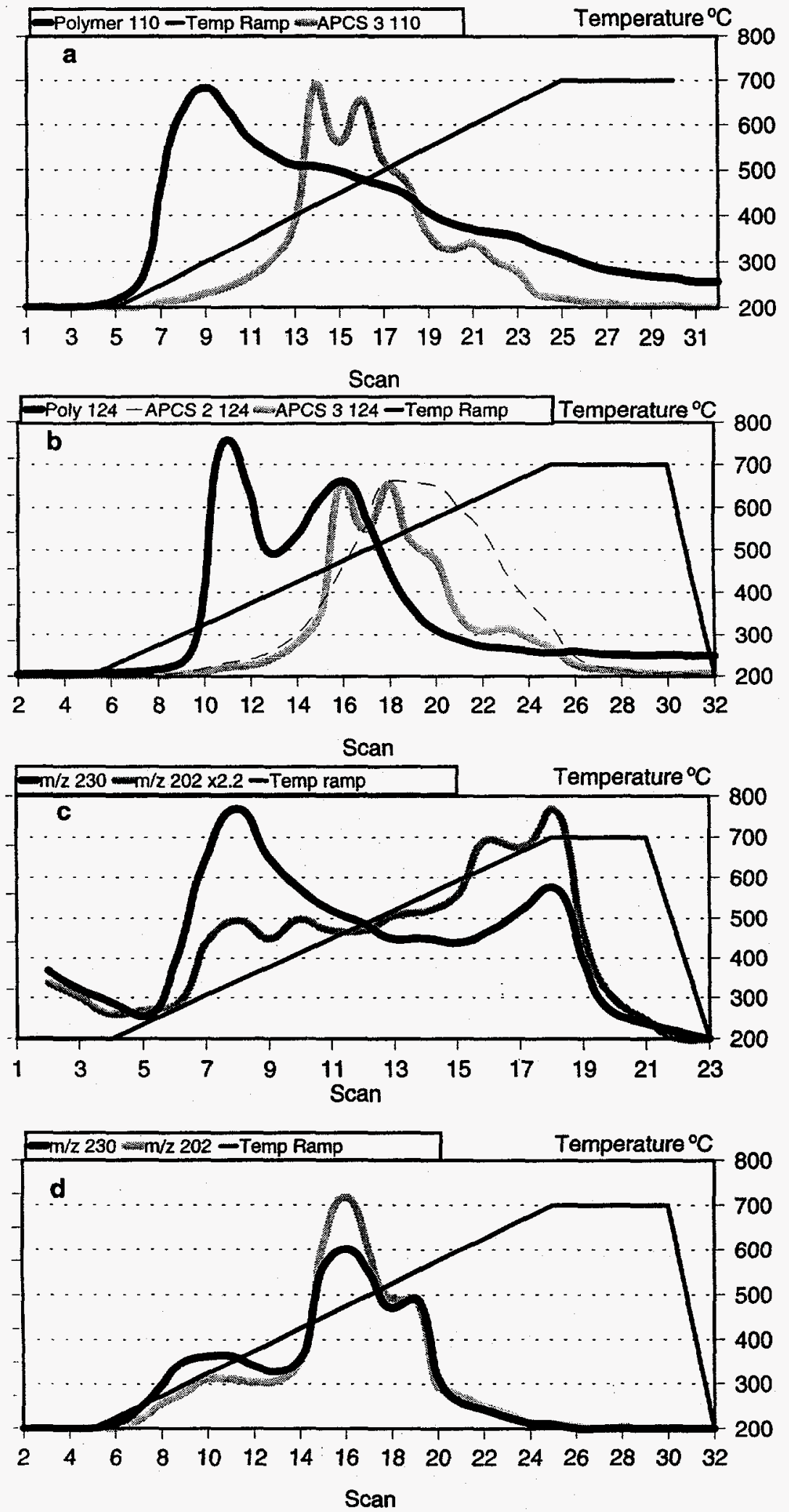

Figure 1. Individual ion pyrograms from DCIMS for (a) Pocahontas (APCS 5) pyridine extract; (b) Pocahontas whole coal; (c) Pittsburgh (APCS 4) pyridine extract; and (d) $\mathrm{m} / \mathrm{z}=124$, for the polymer (I), Wyodak-Anderson subbituminous coal (APCS 2) pyridine extract, and Illinois No. 6 (APCS 3) pyridine extract. 